INTERNATIONAL HANDBOOK

OF UNIVERSITIES

AND OTHER INSTITUTIONS

OF HIGHER EDUCATION

EIGHTH EDITION 


\section{Companion Volume:}

Commonwealth Universities Yearbook, Joint Editors Sir Hugh W. Springer and T. Craig. ISBN 085143063 5; ISSN 0069.7745. (Association of Commonwealth Universities, 36 Gordon Square, London WC1H OPF).

Every three years the International Association of Universities also edits the WORLD LIST OF UNIVERSITIES

This is a concise directory covering more than 6000 universities and other institutions of higher education throughout the world, including the Commonwealth and the United States of America, and providing information about the principal national and international organizations concerned with higher education. 


\section{INTERNATIONAL HANDBOOK OF UNIVERSITIES}

AND OTHER INSTITUTIONS

OF HIGHER EDUGATION

EIGHTH EDITION

$W$
DE
$G$

DE GRUYTER • BERLIN • NEW YORK 


\title{
Editor
}

\section{J. AITKEN}

\author{
Assistant Editor \\ ANN C. M. TAYLOR
}

(C) The International Association of Universities 1981

All rights reserved. No part of this publication may be reproduced or transmitted, in any form or by any means, without permission.

Published every three years.

Eighth Edition 1981 by

THE MACMILLAN PRESS LTD

London and Basingstoke, and

WALTER DE GRUYTER

Berlin and New York.

ISBN 3110080788

Printed and bound in Great Britain 